\title{
Motivations affecting attitude towards information: development of a conceptual model
}

\author{
Daniele Doneddu ${ }^{1,2}$ \\ ${ }^{1}$ School of Management, Swansea University, Swansea SA1 8EN, UK \\ ${ }^{2}$ SCIENTIA group, Swansea, UK \\ d.doneddu@swansea.ac.uk
}

\begin{abstract}
Electronic word of mouth (eWOM) plays an important part in our everyday life. When seeking information online through eWOM, our attitude towards specific information is inevitably affected by a wide range of factors and motives. Identifying and studying how motivations to seek eWOM affect our attitude towards said information may play a role to help us devise strategies to deal with new products, services and technologies as they are released in to the wild and get exposure to consumers. The aim of this research is to develop a model to study how certain specific motivations may affect the attitude individuals hold towards eWOM information. This paper develops a set of hypotheses to help evaluate how motivations affects the information seeker's attitude towards the information. Future empirical research will test the proposed hypotheses to advance our understanding of the role of motivations when seeking eWOM information.
\end{abstract}

Keywords: electronic word of mouth, eWOM, attitude towards information, information seeking, motivations

\section{Introduction}

The advent of the Internet, social media and the advancements in e-commerce-type transactions (and related security technologies development) have provided traditional word of mouth communication with the new, powerful approach of electronic word of mouth (eWOM), to greatly support the process of information seeking. Ismagilova, Dwivedi, Slade and Williams [1] provide a thorough and comprehensive compendium on eWOM, starting with a new and improved definition: "the dynamic and ongoing information exchange process between potential, actual or former consumers regarding a product, service, brand or company, which is available to a multitude of people and institutions via the Internet” (p.18).

The eWOM related research field is now being populated with a substantial body of empirical evidence that shows the significant impact eWOM has within consumer behaviour and information process behaviour. In particular, in previous studies significant evidence has been produced showing the impact of eWOM on information adoption [2], intention to buy [3], information overload [4], and change in consumer's attitude [5]. 
Most of the studies on eWOM communications paid attention on changes in consumer's attitude towards products [5], brands [6] or website [7]. However, the existing literature has not thoroughly identified and investigated which factors affect attitude towards information. Additionally, a limited number of studies has investigated how motivations to search for online information affect consumer's attitude towards information. Since consumers' attitude can influence consumers' decision making and, as a result, sales [8], the study of the factors affecting consumers' attitude has importance from both theoretical and managerial perspectives. The identification and study of how motivations to seek eWOM affect our attitude towards said information may play a role to help us devise strategies to deal with new products, services and technologies as they are released in to the wild and get exposure to consumers. As a result, the aim of this research is to develop a model to study how certain specific motivations may affect the attitude individuals hold towards eWOM information.

Previous studies found that motivations to engage in eWOM can affect frequency of eWOM communications and intention to buy. However, the impact of motivations to seek information on consumer's attitude towards information has, to the best of the author's knowledge, so far not been investigated. In-depth understanding of factors affecting consumer's attitude can improve information adoption, intention to buy and, as a result, level of sales. In light of the potential substantial impact of such factors on information adoption, intention to buy and resulting sales, the development of a conceptual model on motivations to seek information and attitude towards information will advance understanding of information processing.

The aim of this paper is to present a conceptual model of the relationships between motivation to seek eWOM communications (e.g. social approval, social interaction benefit, risk reduction, reduction of search time and effort, and getting product (usage) information) and attitude towards information. The rationale of this paper is that different motivations can influence consumer's attitude towards information. The following section explores the key literature on attitude and motivations to seek eWOM communication. Next, the conceptual model and hypotheses are presented. Finally, the paper is concluded and directions for future research are outlined.

\section{Literature Review}

Attitude is defined as an evaluation of an entity with some degree of disfavour or favour [9]. Existing studies on eWOM communications found that eWOM communication can influence reviewer's attitude towards products [10], brands [6], websites [7]. Researchers found consumers' attitude to be influenced by different factors, such as: source credibility, message format, quality, type of message, volume, valence, extremity, and subjectivity [11], [10], [12, 13]. There is, however, a lack of studies that have investigated how motivations to seek eWOM can influence consumer's attitude.

Previous studies found that there are several motivation for seeking eWOM communication, such as risk reduction, social approval, reduction of search time and effort, getting product (usage) information and social interaction benefits [14, 15]. Some researchers also investigated the connection between motivations to seek eWOM and behavioural intentions / consumers behaviour. For example, Hennig- 
Thurau \& Walsh [14] investigated the motivations for consumers to retrieve other consumers' online articulations, and their impact on consumer buying and communication behaviour. Furthermore, again Hennig-Thurau and co-authors [16] studied the motives of consumers' online articulations and their resulting behaviour (frequency of platform visits, number of comments).

Scholars call for further investigation on the effect of motivations on consumers' behaviour [14]. Thus, the focus of this research, which emphasises its original contribution to knowledge enhancing the theory of information processing, is to investigate the effect of motivations to seek eWOM communications on perceived attitude towards information, an aspect which has not been studied before.

\section{Conceptual model}

This section discusses each of the constructs of the proposed research model and presents the proposed hypotheses. The research model (see Figure 1) is based on the framework proposed by Henning-Thurau and Walsh [14], which identified the main motivations for people to seek information online.

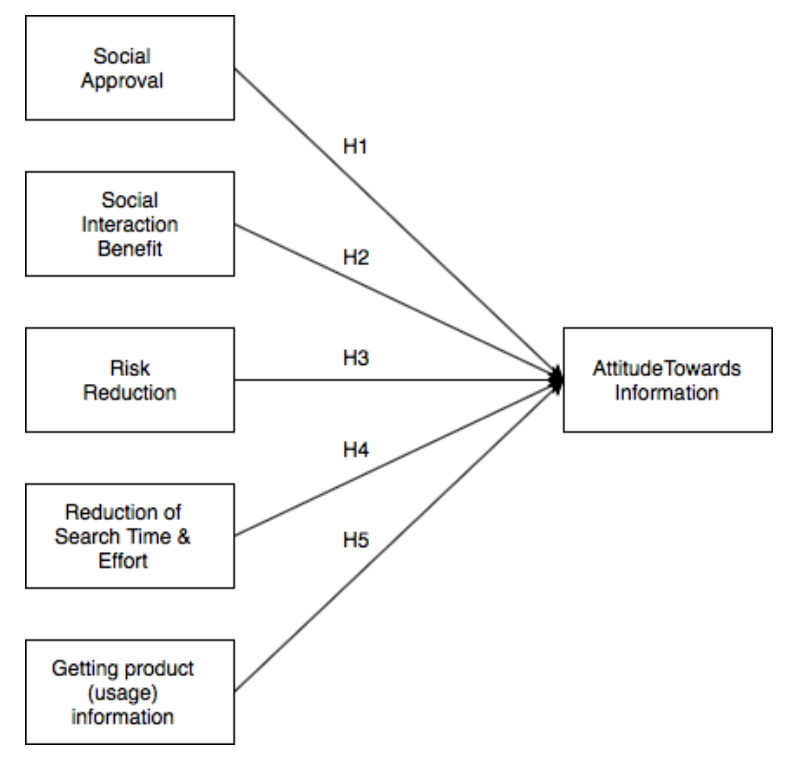

Figure 1 Proposed Research Model

\subsection{Social approval}

According to Hennig-Thurau and Walsh [14], social approval is connected to information search process for the social function of consumption. Individuals search for eWOM communication in order to buy a product/service which is accepted by other people. Furthermore, using eWOM communications individuals can compare their 
existing ideas about a product/service with other people or receive other individuals' approval of the purchase decision [14, 17]. Previous studies found that social approval is one of the motivations for people to search for articulations of others online [14, 18-21]. It was also found that social approval influence consumer's behaviour online $[14,19]$. As a result, it is proposed that:

H1: Social approval has a positive effect on consumer's attitude towards eWOM communications.

\subsection{Social interaction benefits}

By using the Internet individuals can have a sense of belonging to a community by looking for other consumers' postings on online eWOM platforms. When investigating motivations to search information about product/services, online previous studies found that the benefits of social interaction motivate consumers to seek eWOM and affect online consumer behaviour [15, 22]. The following hypothesis is proposed:

H2: Social interaction benefit has a positive effect on consumer's attitude towards eWOM communications.

\subsection{Risk reduction}

Individuals use eWOM communication to decrease the perceived risk in decision making [23]. Previous studies found that people rely on interpersonal sources of information when they perceived a purchase as risky [24]. eWOM information gives people an opportunity to get clarification and feedback which will decrease their decision making uncertainly about a product or service. As a result, using information from eWOM communication allows receiver of this information to build confidence in purchase decision and reduce perceived risk of the purchase [25]. Previous studies found that risk reduction is one of the main motivations for people to read online information from others on Internet [14, 19, 22, 23, 26-28]. It was also found that risk reduction influences consumers' behaviour online [14]. As a result, the following hypothesis is proposed:

H3: Risk reduction has a positive effect on consumer's attitude towards eWOM communications.

\subsection{Reduction of search time and effort}

Individuals use eWOM communication to reduce search time and effort in making purchase decisions [23]. High volume of available information online and a wide range of products/services can make consumers face difficulties when it comes to know all the available alternatives [17]. eWOM can be a convenient way to obtain necessary buying-related information with time reduction on searching activities. Previous studies found that reduction of search time and effort is an important motivation for people to seek information using eWOM communications and it has an impact on consumer behaviour online [14, 15, 19, 22, 29]. Thus, the following hypothesis is proposed: 
H4: Reduction of search time and effort has a positive effect on consumer's attitude towards eWOM communications.

\subsection{Getting product (usage) information}

Individuals read eWOM communication to receive product-related information [14]. By using eWOM communications people can get information about new products/services and learn how to use them. It was examined by previous studies that getting product (usage) information influences people to seek for information online $[22,23]$, which could lead to a change in attitude towards eWOM communications. Thus, it is proposed that:

H5: Getting product (usage) information has a positive effect on consumer's attitude towards eWOM communications.

\section{Conclusion}

The aim of this research is to develop a conceptual model to study how certain specific motivations may affect the attitude individuals hold towards eWOM information. Based on the framework proposed by Hennig-Thurau and Walsh [14], this paper develops a set of hypotheses to help evaluate how motivations affects the information seeker's attitude towards the information. Investigating the impact of motivation on attitude towards information is important for marketers. It has been previously shown that attitude towards eWOM communications affects information usefulness, which in turn affects information adoption and intention to buy [30]. Understanding how motivations can lead to a positive or negative attitude towards information will help to gain a greater understanding of eWOM communications by investigating determinants of attitude towards eWOM information, which will lead to the development of better marketing strategies. The findings from this study will lead to a richer understanding of the factors which affect consumer's attitude towards information and this research will therefore advance current understanding of the role of motivations to seek eWOM in an information seeking situation. The next step for this research is to validate the proposed hypotheses as follows: 1) data collection using questionnaires 2) Structural equation modelling to be used to test hypothesised relationships among constructs, using the SPSS ${ }^{\circledR}$ Amos software from IBM ${ }^{\circledR}$.

\section{$5 \quad$ References}

1. Ismagilova, E., Dwivedi, Y.K., Slade, E., Williams, M.D.: Electronic word of mouth (eWOM) in the marketing context: A state of the art analysis and future directions. Springer (2017)

2. Cheung, R.: The influence of electronic word-of-mouth on information adoption in online customer communities. Global Economic Review 43, 42-57 (2014)

3. Tsao, W.-C., Hsieh, M.-T., Shih, L.-W., Lin, T.M.: Compliance with eWOM: The influence of hotel reviews on booking intention from the perspective of consumer conformity. International Journal of Hospitality Management 46, 99-111 (2015) 
4. Furner, C.P., Zinko, R.A.: The influence of information overload on the development of trust and purchase intention based on online product reviews in a mobile vs. web environment: an empirical investigation. Electronic Markets 27, 211-224 (2017)

5. Huang, G.-H., Korfiatis, N.: Trying before buying: The moderating role of online reviews in trial attitude formation toward mobile applications. International Journal of Electronic Commerce 19, 77-111 (2015)

6. Sandes, F.S., Urdan, A.T.: Electronic word-of-mouth impacts on consumer behavior: Exploratory and experimental studies. Journal of International Consumer Marketing 25, 181197 (2013)

7. $\quad$ Chih, W.-H., Wang, K.-Y., Hsu, L.-C., Huang, S.-C.: Investigating electronic wordof-mouth effects on online discussion forums: the role of perceived positive electronic word-ofmouth review credibility. Cyberpsychology, Behavior, and Social Networking 16, 658-668 (2013)

8. Cheung, C.M., Thadani, D.R.: The impact of electronic word-of-mouth communication: A literature analysis and integrative model. Decision support systems 54, 461470 (2012)

9. Eagly, A.H., Chaiken, S.: The advantages of an inclusive definition of attitude. Social cognition 25, 582-602 (2007)

10. Ladhari, R., Michaud, M.: eWOM effects on hotel booking intentions, attitudes, trust, and website perceptions. International Journal of Hospitality Management 46, $36-45$ (2015)

11. Jeong, H.-J., Koo, D.-M.: Combined effects of valence and attributes of e-WOM on consumer judgment for message and product: The moderating effect of brand community type. Internet Research 25, 2-29 (2015)

12. Lee, J., Park, D.-H., Han, I.: The effect of negative online consumer reviews on product attitude: An information processing view. Electronic commerce research and applications 7, 341-352 (2008)

13. Lee, M., Rodgers, S., Kim, M.: Effects of valence and extremity of eWOM on attitude toward the brand and website. Journal of Current Issues \& Research in Advertising 31, $1-11$ (2009)

14. Hennig-Thurau, T., Walsh, G., Walsh, G.: Electronic word-of-mouth: Motives for and consequences of reading customer articulations on the Internet. International journal of electronic commerce 8, 51-74 (2003)

15. Khammash, M., Griffiths, G.H.: ‘Arrivederci CIAO. com, Buongiorno Bing. com’Electronic word-of-mouth (eWOM), antecedences and consequences. International Journal of Information Management 31, 82-87 (2011)

16. Hennig-Thurau, T., Gwinner, K.P., Walsh, G., Gremler, D.D.: Electronic word-ofmouth via consumer-opinion platforms: What motivates consumers to articulate themselves on the Internet? Journal of interactive marketing 18, 38-52 (2004)

17. Han, S.M.: Motivations for providing and seeking eWOM: a cross cultural comparison of US and Korean college students. ProQuest (2000)

18. Huang, L., Shao, J., Wang, W.: Research on the relationships between hotel internet word-of-mouth and customers' behavior intention based on trust. In: Information Management, Innovation Management and Industrial Engineering (ICIII), 2013 6th International Conference on, pp. 250-254. IEEE, (Year) 
19. Kim, E.E.K., Mattila, A.S., Baloglu, S.: Effects of gender and expertise on consumers' motivation to read online hotel reviews. Cornell Hospitality Quarterly 52, 399-406 (2011)

20. Matta, V., Frost, R.: Motivations of electronic word-of-mouth communications by reviewers: a proposed study. (2011)

21. Yap, K.B., Soetarto, B., Sweeney, J.C.: The relationship between electronic word-ofmouth motivations and message characteristics: The sender's perspective. Australasian Marketing Journal (AMJ) 21, 66-74 (2013)

22. Burton, J., Khammash, M.: Why do people read reviews posted on consumer-opinion portals? Journal of Marketing Management 26, 230-255 (2010)

23. Goldsmith, R.E., Horowitz, D.: Measuring motivations for online opinion seeking. Journal of interactive advertising 6, 2-14 (2006)

24. Bansal, H.S., Voyer, P.A.: Word-of-mouth processes within a services purchase decision context. Journal of service research 3, 166-177 (2000)

25. Ha, H.-Y.: The effects of consumer risk perception on pre-purchase information in online auctions: Brand, word-of-mouth, and customized information. Journal of ComputerMediated Communication 8, JCMC813 (2002)

26. Akyüz, A.: Determinant factors influencing eWOM. Mediterranean Journal of Social Sciences 4, 159 (2013)

27. Awad, N.F., Ragowsky, A.: Establishing trust in electronic commerce through online word of mouth: An examination across genders. Journal of Management Information Systems 24, 101-121 (2008)

28. Zhang, Y., Lv, T.: Analysis of the relationship between involvement and the internet word-of-mouth. In: Network Infrastructure and Digital Content, 2010 2nd IEEE International Conference on, pp. 1018-1024. IEEE, (Year)

29. Munzel, A., H. Kunz, W.: Creators, multipliers, and lurkers: who contributes and who benefits at online review sites. Journal of Service Management 25, 49-74 (2014)

30. Erkan, I., Evans, C.: The influence of eWOM in social media on consumers' purchase intentions: An extended approach to information adoption. Computers in Human Behavior 61, 47-55 (2016) 